\title{
Errors in English Essay Writing from a Syntactic Perspective
}

\author{
Isti'anatul Hikmah \\ English Education Program, Universitas Sarjanawiyata Tamansiswa, Indonesia \\ ihikmah99@gmail.com
}

\begin{tabular}{|c|c|}
\hline fo & $\mathrm{ACT}$ \\
\hline $\begin{array}{l}\text { Article History } \\
\text { - Article Received } \\
19^{\text {th }} \text { August } 2019 \\
\text { - Article Reviewed } \\
25^{\text {th }} \text { September } 2019 \\
\text { - Article Accepted } \\
4^{\text {th }} \text { October } 2019 \\
\text { Keywords } \\
\text { syntactic errors } \\
\text { syntactic perspective } \\
\text { word } \\
\text { phrase } \\
\text { clause }\end{array}$ & $\begin{array}{l}\text { This study discuses errors in English essay writing from syntactic perspective. } \\
\text { Syntactic theory was used to analyze data while the data of this study were English } \\
\text { essay writing written by university students. The method of this study was } \\
\text { qualitative study which was divided into three namely data collecting method, data } \\
\text { analysis method, and presentation of data analysis. Data of this study were collected } \\
\text { using simak method. It meant monitoring the language used which was in the form } \\
\text { of written text. Then there are two techniques used to collect data namely } \\
\text { documentation and noted technique. Descriptive analytic was used to analyze data } \\
\text { using syntactic theory. Informal method was used to present the result of data } \\
\text { analysis in the form of sentences. There were two results of this study. Firstly, it } \\
\text { showed that there were nineteen words, thirteen phrases, and thirteen clauses were } \\
\text { found as errors in university students' English essay writing. Secondly, university } \\
\text { students need to master English grammar to minimize syntactic errors in English } \\
\text { essay writing. }\end{array}$ \\
\hline
\end{tabular}

\section{INTRODUCTION}

Essay is one writing material which must be mastered by university students. It is longer than paragraph, and it has some types like opinion, descriptive, process, narrative essay, and others. Savage and Mayer[1]stated that essay is a text that is longer than the paragraph and has three main parts, namely introduction, body, and conclusion. These parts must be found in an essay. If one of them is erased, an essay may have minus point or it can be said as incomplete essay.

In order to write a good essay, those three main parts must be supported by unity and coherence; and syntactic side. Unity and coherence relates to linkage between the contents of essay while syntactic side refers to the grammatical structure of sentences. Unity and coherence of essay will be good if it is supported by grammatical sentences. In this part, some university students usually have difficulties in syntactic part or in writing grammatical sentences.

Syntactic errors in writing essay were found in some students' essay. These errors appeared in the form of ungrammatical sentences used by them. Some of them had difficulties to write grammatical sentences because they do not know well about it. Tallerman[2] said that syntactic is an arrangement of sentence. In other words, it is a sentence formation which follows the rules used by each languages. Rules of sentence writing similar to grammar of language which means the way a sentence is formed in a language. Ramlan[3] explained that syntactic is a branch of linguistics which discusses discourse, sentence, clause, and phrase. It can be said that it covers word, phrase, clause, and sentence so it describes parts of sentences itself.

The parts of syntactic in English essay writing are usually written incorrectly by some students. When it was done, their essay writing will have less point because they may not able to deliver properly the contents of their essay writing. Therefore, their reader may confuse about the content on their essay. Two examples of error syntactic in essay writing are runon sentence and fragment. One example of run-on sentence is Students admire Ki Hadjar Dewantara they apply his ideas. On that sentence, there are two independence clauses without coordinating conjunction or punctuation, so that sentence should be written like Students admire Ki Hadjar Dewantara, and 


\section{Hikmah, Isti'anatul \\ Errors in English Essay Writing from a Syntactic Perspective}

they apply bis ideas. Then one example of fragment in an English essay is Finding job easier in my life. This sentence misses verb, so it should be like Finding job is easier in my life. Those two example are easily found in university students' English essay writing. When their lecturer explained about English grammar before writing an English essay, they always said that they understood. In contrary, the situation was different when they started to write. They suddenly forget about English grammar, and they wrote anything on their mind without thinking their English grammar. This situation needs serious care because English essay writing is one of important subject in English education. Consequently, students must pay attention to their syntactic part on English essay writing.

The errors of syntactic part on English essay writing can be found in many university students' English essay writing. One of them can be seen in English essay writing which was written by students of English Education Program, Universitas Sarjanawiyata Tamansiswa. One simple example of syntactic error is in word error that is a word babbit which must be written habit. It happened because they thought that habbit was similar to rabbit, so they have misconception for some words on their mind.

Those several examples mistakes in syntactic part became the first reason of doing this study. As a result, it was done because the writer want to find other syntactic errors in English essay writing focusing on word, phrase, and clause errors; and to observe the reasons behind those mistakes. Finding them become one of ways to minimize errors in university students' English essay writing.

\section{LITERATURE REVIEW}

\section{a. Definition of Syntactic}

Richard[4] mentioned that syntax is the study of combining words into sentences. Thus it can be said that arranging grammatical sentences based on grammatical rules used by each languages is called syntax. The point is following their rules.

In syntax there are syntactic units. The units consist of functions, categories, and syntactic elements. Syntactic functions include subject, predicate, object, complement, and description. While the syntactic category consists of nouns, pronominal, verbs, adjectives, adverbs, prepositions, conjunctions, interjection, and determiners. Furthermore, the syntactic element includes the word which is the smallest object of syntactic study and the sentence which is the object of the largest syntactic study.

\section{b. Function of Syntax}

The syntactic function includes five sections namely subject, predicate, object, and adverb (Chaer, 2008: 207). First is subject. The part of the sentence that shows the doer, figure (thing), all things, or problems that become subject of the conversation. The forms of subject are usually words or phrases, clauses, verbal phrases. The subject can also be identified by using the question words who (who), what (which) to the predicate. If the answer is not logical then there is no subject.

Second is predicate. It states the condition of subject, the nature, situation, status, character or identity of subject, or the amount of something possessed by subject. It can be said that predicate is the part of the sentence except subject. It can be a verb/ verb phrase, adjectives, adverbs and nouns.

Third is object. Objects are part of sentences that complete the Predicate. The object is generally filled with nouns, nominal phrases, or clauses. The location of the object is always behind the Predicate in the form of a transitive verb, that is, a verb that requires the object. If the Predicate is filled with intransitive verbs then the object is not needed so that the presence of the object in the sentence.

Fourth is complement. It is part of sentence that completes predicate, and it is generally behind the predicate in the form of verbs. Fifth is adverb. It explains various things about the other parts of the sentence like subject, object, predicate, and verb. In addition, the position of the information can be at the beginning, middle and end of the sentence.

\section{c. Syntactic Units}

Syntactic units contain five parts namely word, phrase, clause, sentence, and discourse[5]. It means that syntactic covers minor area that is word to major area that is discourse. In this syntactic units, sentence and discourse will not be explained because the focus of this study is only three areas namely word, phrase, and clause.

At the level of syntax, words are the smallest unit that is hierarchically a component forming larger syntactic units, namely phrases. The word as a syntactic unit, that is, in relation to the elements forming a larger syntactic unit, namely phrases, 
clauses, and sentences. As a small unit in syntax, the word plays a role as a syntactic function filler, as a marker of syntactic categories, and as a coupling in uniting units or parts of syntactic units.

Phrases are a linguistic meaning, and phrases are linguistic units that are bigger than words and smaller than clauses and sentences. Phrases are a collection of non-predicative words. This means that the phrase has no predicate in its structure. That's what distinguishes phrases from clauses and sentences.

A clause is a level in syntax that is above the level of a phrase and below the level of a sentence. A clause is a syntactic unit in the form of predicative constructs of words. That is, in the construction there are components, in the form of words or phrases, which function as predicates; and the other functions as a subject, as an object, and as an adverb.

\section{d. Some Previous Studies}

There are two previous studies in this study. First is Promsupa, Varasarin, dan Brudhiprabha[7] who analyzed grammatical errors in English writing by Thai University students. It was stated that the students made grammar mistakes 2.218 times. It showed that Thai university students have weak understanding in English grammar. Second is Sawalmeh[8] who examined the error analysis in essays English writing by students in Saudi Arabia. He found ten grammatical errors: verb tense, word order, singular/plural form, subject-verb agreement, double negatives, spellings, capitalizations, articles, sentence fragments, and prepositions. This study also showed that students in Saudi Arabia needs to learn English grammar.

From the two previous studies that have been mentioned, it is said that there are some errors in essay writing that seem to require attention. These mistakes are mostly in grammatical terms. Those two used grammatical point of view to analyze their data. Meanwhile, this study used other theory to analyze the data. It used syntactic theory which covered words, phrases, and clauses. In other words, this study only focused on those three areas.

\section{METHODOLOGY}

Method used in this study was qualitative method. It is an umbrella term for a wide variety of approaches to and methods for the study of natural social life[9]. A wide variety covers spoken and written data which can be collected using interview transcripts, fieldnotes, documents, and others. The method of this study was divided into three. First is data collecting method that is simak. Mahsun[6] stated that simak method means paying attention to the use of language in the spoken or written language. In this study, simak method was used to collect written data of English essay writing. The data were written essays which were collected from forty English Education Program students of Universitas Sarjanawiyata Tamansiswa on third semester academic year 2017/2018 using documentation and noted technique. Collecting data using documentation technique was the first step, so all forty English essays writing was collected. After collecting data, they were noted using noted technique, so they were separated into three parts those were word, phrase, and clause error syntactic. Second was analysis data method namely descriptive analytic. The data were described and analyzed using syntactic theory focusing on three parts namely word, phrase, and clause. The analysis data was divided into three parts those are analysis of word, phrase, and clause. Moreover, finding syntactic errors in each data based on syntactic theory. Third is data analysis presentation namely informal method. It means that the data analysis were explained in the form of sentences. They were written using simple, compound, and complex sentences.

\section{RESULT AND DISCUSSION}

This section is divided into three parts based on the focus of syntactic level analysis. The first part is word syntactic error, the second is phrase syntactic error, and clause syntactic error.

\section{a. Word Syntactic Error in Essay Writing}

Based on the collected data in this study, there were nineteen words syntactic errors which can be seen on table 1 below:

\begin{tabular}{cclc}
\hline No & $\begin{array}{c}\text { Word } \\
\text { Syntactic } \\
\text { Error }\end{array}$ & $\begin{array}{c}\text { Position of } \\
\text { Error }\end{array}$ & Correction \\
\hline $\mathbf{1}$ & Slove & $\begin{array}{l}\text { Inverted } \\
\text { position of } \\
\text { letter (o) and } \\
\text { (l) }\end{array}$ & Solve \\
\hline $\mathbf{2}$ & Traffict & $\begin{array}{l}\text { Excess letter } \\
\text { (t) at the end } \\
\text { of word }\end{array}$ & Traffic \\
& & \\
\hline
\end{tabular}




\begin{tabular}{|c|c|c|c|}
\hline 3 & Importan & $\begin{array}{l}\text { Minus letter } \\
(\mathrm{t}) \text { at the end } \\
\text { of word }\end{array}$ & Important \\
\hline 4 & Jogja & $\begin{array}{l}\text { Incorrect } \\
\text { initial letter }(J)\end{array}$ & Yogya \\
\hline 5 & Jus & $\begin{array}{l}\text { Minus letter } \\
\text { (t) at the end } \\
\text { of word }\end{array}$ & Just \\
\hline 6 & Recorganize & $\begin{array}{l}\text { Excess letter } \\
\text { (c) at the } \\
\text { middle of } \\
\text { word }\end{array}$ & Reorganize \\
\hline 7 & Strategi & $\begin{array}{l}\text { Incorrect } \\
\text { letter (i) }\end{array}$ & Strategy \\
\hline 8 & Minimalis & $\begin{array}{l}\text { Minus letter } \\
\text { (t) at the end } \\
\text { of word }\end{array}$ & Minimalist \\
\hline 9 & Techologic & $\begin{array}{l}\text { Minus letter } \\
\text { (n) before (h) }\end{array}$ & Technologic \\
\hline 10 & Wok & $\begin{array}{l}\text { Minus letter } \\
(\mathrm{r}) \text { before }(\mathrm{k})\end{array}$ & work \\
\hline 11 & Patien & $\begin{array}{l}\text { Minus letter } \\
\text { (t) at the end } \\
\text { of word }\end{array}$ & patient \\
\hline 12 & nerveous & $\begin{array}{l}\text { Excess letter } \\
\text { (e) after (v) }\end{array}$ & nervous \\
\hline 13 & Grammer & $\begin{array}{l}\text { wrong letter } \\
\text { (e) }\end{array}$ & grammar \\
\hline 14 & Combain & $\begin{array}{l}\text { Excess letter } \\
\text { (a) after (b) } \\
\text { and minus } \\
\text { letter (e) at } \\
\text { the end of } \\
\text { word }\end{array}$ & combine \\
\hline 15 & Usefull & $\begin{array}{l}\text { Excess letter } \\
\text { (l) at the end }\end{array}$ & useful \\
\hline 16 & Mak & $\begin{array}{l}\text { Minus letter } \\
\text { (e) at the end } \\
\text { of word }\end{array}$ & make \\
\hline 17 & manag & $\begin{array}{l}\text { Minus letter } \\
\text { (e) at the end } \\
\text { of word }\end{array}$ & manage \\
\hline 18 & interestin & $\begin{array}{l}\text { Minus letter } \\
(\mathrm{g}) \text { at the end } \\
\text { of word }\end{array}$ & interesting \\
\hline 19 & carefull & $\begin{array}{l}\text { Excess letter } \\
\text { (l) at the end } \\
\text { of word }\end{array}$ & careful \\
\hline
\end{tabular}

Table 1. Word Syntactic Error in Essay Writing
There were nineteen word syntactic errors on table 1. They were divided into seven types of errors. First was inverted position of letter in a word as shown on table 1 number 1 , and it occurred only once. The inverted position appeared in a word slove. A position of letter (o) and (I) should be changed, so slove became solve. Second was excess letter at the end of a word as shown on table 1 number 2 like traffic which should be changed into traffic; number 15 like usefull which should be changed into useful; and number 19 like carefull which should be changed into careful. The number of this error was three. Third was excess letter at the middle of a word as shown on table 1 number 6 like recorganize which should be changed into reorganize; number 12 like nerveous which should be changed into nervous; and number 14 like combain which should be changed into combine. The number of them was three. Fourth was minus letter at the end of a word as shown on table 1 number $3,5,8,11,14,16$, 17 , and 18. One example of this error was importan which should be changed into important. It must have a letter $(t)$ at the end of the word. Fifth was minus letter at the middle of a word as shown on table 1 number 9 like techologic which should be changed into technologic; and number 10 like wok which should be changed into work. The amount of them was two. Sixth was incorrect initial letter of city name as shown on table 1 number 4 like Jogja. It refers to lack of understanding of standard word for city names in academic writing. Jogja is used in the non-academic writing, so it is better to use Yogya or Yogyakarta in an academic writing like essay. The number of it was one. Seventh was incorrect letter in a word as shown on table 1 number 7 like strategi which should be changed into strategy; and number 13 like grammer which should be changed into grammar. This error was influenced by the Indonesian language like example number 7 and the pronunciation of the words in English like example number 13. The influence of Indonesian language means that university students still use their Indonesian grammar in English essay writing. This situation is reasonable because this study were done in Indonesia so the participants of this study always use Indonesian language in their daily life, but they can minimize it by adding a portion of the practice of writing an English essay. While the pronunciation of the words in English happened because some university students wrote the words based on their pronunciation. This can be seen in the example in datum number thirteen for the word grammer. The pronunciation of the word grammar in English is 
/'græm.ər/. It usually happened when they are in hurry. They have limit time to write English essay, so they only write what is on their mind without rechecking it.

The seven types of word syntactic errors can be seen on table 2 below:

\begin{tabular}{clc}
\hline No & \multicolumn{1}{c}{ Word Syntactic Errors } & Total \\
\hline $\mathbf{1}$ & $\begin{array}{l}\text { Inverted position of a letter } \\
\text { in a word }\end{array}$ & 1 \\
\hline $\mathbf{2}$ & $\begin{array}{l}\text { Excess letter at the end of a } \\
\text { word }\end{array}$ & 3 \\
\hline $\mathbf{3}$ & $\begin{array}{l}\text { Excess letter at the middle of } \\
\text { a word }\end{array}$ & 3 \\
\hline $\mathbf{4}$ & $\begin{array}{l}\text { Minus letter at the end of a } \\
\text { word }\end{array}$ & 8 \\
\hline $\mathbf{5}$ & $\begin{array}{l}\text { Minus letter at the middle of } \\
\text { a word }\end{array}$ & 2 \\
\hline $\mathbf{6}$ & $\begin{array}{l}\text { Incorrect initial letter of city } \\
\text { name }\end{array}$ & 1 \\
\hline $\mathbf{7}$ & Incorrect letter in a word & 2 \\
\hline
\end{tabular}

Table 2. Seven Types of Word Syntactic Errors in

$$
\text { Essay Writing }
$$

\section{b. Phrase Syntactic Error in Essay Writing}

Based on the collected data in this study, there were thirteen phrases syntactic errors which can be seen on table 3 below:

\begin{tabular}{|c|c|c|c|}
\hline No & $\begin{array}{c}\text { Phrase } \\
\text { Syntactic } \\
\text { Error }\end{array}$ & $\begin{array}{l}\text { Position } \\
\text { of Error }\end{array}$ & Correction \\
\hline 1 & $\begin{array}{l}\text { Working or } \\
\text { hang out }\end{array}$ & $\begin{array}{l}\text { Incorrect } \\
\text { pattern of } \\
\text { parallel } \\
\text { structure }\end{array}$ & $\begin{array}{l}\text { - } \frac{\text { Working or }}{\text { hanging out }} \\
\text { - } \frac{\text { Work or }}{\text { hang out }}\end{array}$ \\
\hline 2 & $\begin{array}{l}\text { Is can } \\
\text { minimize }\end{array}$ & $\begin{array}{l}\text { There is to } \\
\text { be (is) } \\
\text { before } \\
\text { modal } \\
\text { (can) }\end{array}$ & Can minimize \\
\hline 3. & To finished & $\begin{array}{l}\text { To is not } \\
\text { followed } \\
\text { by V2 or } \\
\text { V3 }\end{array}$ & To finish \\
\hline 4 & Many school & $\begin{array}{l}\text { Incorrect } \\
\text { plural form } \\
\text { of a word } \\
\text { school }\end{array}$ & Many schools \\
\hline
\end{tabular}

\begin{tabular}{|c|c|c|c|}
\hline 5 & A organizer & $\begin{array}{l}\text { Incorrect } \\
\text { use of } \\
\text { article } a\end{array}$ & An organizer \\
\hline 6 & $\begin{array}{l}\text { Many } \\
\text { student }\end{array}$ & $\begin{array}{l}\text { Incorrect } \\
\text { plural form } \\
\text { of a word } \\
\text { student }\end{array}$ & Many students \\
\hline 7 & A hour & $\begin{array}{l}\text { Incorrect } \\
\text { use of } \\
\text { article } a\end{array}$ & An hour \\
\hline 8 & Many time & $\begin{array}{l}\text { Incorrect } \\
\text { plural form } \\
\text { of a word } \\
\text { time }\end{array}$ & Many times \\
\hline 9 & A students & $\begin{array}{l}\text { Incorrect } \\
\text { singular } \\
\text { form of a } \\
\text { word } \\
\text { student }\end{array}$ & A student \\
\hline 10 & Can good & $\begin{array}{l}\text { Minus be } \\
\text { after can }\end{array}$ & Can be good \\
\hline 11 & $\begin{array}{l}\text { Road can be } \\
\text { overcoming } \\
\text { the traffic or } \\
\text { subtract }\end{array}$ & $\begin{array}{l}\text { Incorrect } \\
\text { pattern of } \\
\text { parallel } \\
\text { structure }\end{array}$ & $\begin{array}{l}\text { Road can be } \\
\text { overcoming } \\
\text { the traffic or } \\
\text { subtracting }\end{array}$ \\
\hline 12 & $\begin{array}{l}\text { read book, } \\
\text { using } \\
\text { internet, and } \\
\text { ask friends }\end{array}$ & $\begin{array}{l}\text { Incorrect } \\
\text { pattern of } \\
\text { parallel } \\
\text { structure }\end{array}$ & $\begin{array}{l}\text { - } \underline{\text { reading }} \\
\text { book, using } \\
\text { internet, } \\
\text { and asking } \\
\text { friend } \\
\text { - } \frac{\text { read book, }}{\text { use }} \\
\text { internet, } \\
\text { and ask } \\
\text { friends }\end{array}$ \\
\hline 13 & $\begin{array}{l}\text { The colour } \\
\text { red }\end{array}$ & $\begin{array}{l}\text { Incorrect } \\
\text { pattern of } \\
\text { English } \\
\text { phrase }\end{array}$ & $\begin{array}{l}\text { The red } \\
\text { colour }\end{array}$ \\
\hline
\end{tabular}

Table 3. Phrase Syntactic Error in Essay Writing

There were thirteen phrases syntactic errors on table 3. They were divided into eight types of errors. First was incorrect pattern of parallel structure as shown on table 3 number 1,11, and 12 . One example of this error was working or hang out which should be changed into working or hanging out or work or hang out. This example was incorrect because a word before and after or should be in the form of $v$-ing or $v 1$. They happened for several reasons. The number of this mistake was three. Second was to be before modal as 
shown on table 3 number 2 like is can minimize. This error can be changed into can minimize because modals should be followed by v1. Third is to $+\mathrm{v} 2 / \mathrm{v} 3$ as shown on table 3 number 3 like to finished. This error can be changed into to finish because to infinitive must be followed by v1. The number of this error was one. Fourth was incorrect plural form of a word as shown on table 3 umber 4, 6, and 8 . One example of this error was many school which should be changed into many schools because there is quantifier many. The number of this error was three. Fifth was incorrect singular form of a word as shown on table 3 number 9 like a students. It should be a student because there is article $a$. The number of this error was one. Sixth was incorrect use of article $a$ as shown on table 3 number 5 and 7. An example of this error was a organizer which should be changed into an organizer. The number of this error was two. Seventh was minus be after modal as shown on table 3 number 10 like can good. This error should be changed into can be good because modal cannot be followed directly by adjective. The number of this error was one. Eighth was incorrect pattern of English noun phrase as shown on table 3 number 13 like the colour red. This error should be changed into the red colour because the pattern of noun phrase is adjective followed by noun. In addition, this mistake happened because of the pattern of noun phrase in Indonesian language is adjective + noun like warna merah. Some university students used their Indonesian pattern of noun phrase in English essay writing.

The most phrase errors did by university students in English essay writing were incorrect pattern of parallel structure and incorrect plural form of a word. This situation shows that university students have weak ability to master English grammar. Consequently, they should improve their English grammar in writing, so they can avoid silly mistakes like incorrect article $a$ and incorrect pattern of phrase.

The eight types of phrase syntactic errors can be seen on table 4 below:

\begin{tabular}{clc}
\hline No & \multicolumn{1}{c}{ Word Syntactic Errors } & Total \\
\hline $\mathbf{1}$ & $\begin{array}{l}\text { Incorrect pattern of parallel } \\
\text { structure }\end{array}$ & 3 \\
\hline $\mathbf{2}$ & to be before modal & 1 \\
\hline $\mathbf{3}$ & $\begin{array}{l}\text { to }+\mathrm{v} 2 / \mathrm{v} 3 \\
\mathbf{4}\end{array}$ & $\begin{array}{l}\text { Incorrect plural form of a } \\
\text { word }\end{array}$ \\
\hline $\mathbf{5}$ & $\begin{array}{l}\text { Incorrect singular form of a } \\
\text { word }\end{array}$ & 1 \\
\hline $\mathbf{6}$ & Incorrect use of article $a$ & 2 \\
\hline
\end{tabular}

\begin{tabular}{cll}
\hline $\mathbf{7}$ & minus be after modal & 1 \\
\hline $\mathbf{8}$ & $\begin{array}{l}\text { Incorrect pattern of English } \\
\text { noun phrase }\end{array}$ & 1 \\
\hline
\end{tabular}

Table 4. Eight Types of Phrase Syntactic Errors in Essay Writing

\section{c. Clause Syntactic Error in Essay Writing}

Based on the collected data in this study, there were thirteen clauses syntactic errors which can be seen on table 5 below:

\begin{tabular}{|c|c|c|c|}
\hline No & $\begin{array}{c}\text { Clause } \\
\text { Syntactic } \\
\text { Error }\end{array}$ & $\begin{array}{l}\text { Position of } \\
\text { Error }\end{array}$ & Correction \\
\hline 1 & $\begin{array}{l}\text { it is can } \\
\text { make many } \\
\text { traffic } \\
\text { problems }\end{array}$ & $\begin{array}{l}\text { There is to be } \\
\text { before modal } \\
\text { can }\end{array}$ & $\begin{array}{l}\text { it can make } \\
\text { many traffic } \\
\text { problems }\end{array}$ \\
\hline 2 & $\begin{array}{l}\text { that is the } \\
\text { simple ways } \\
\text { to solve the } \\
\text { traffic } \\
\text { problems in } \\
\text { Yogyakarta }\end{array}$ & $\begin{array}{l}\text { Subject and to } \\
\text { be do not } \\
\text { show plural }\end{array}$ & $\begin{array}{l}\text { those are the } \\
\text { simple ways } \\
\text { to solve the } \\
\text { traffic } \\
\text { problems in } \\
\text { Yogyakarta }\end{array}$ \\
\hline 3 & $\begin{array}{l}\text { the solution } \\
\text { is be made } \\
\text { in Indonesia }\end{array}$ & $\begin{array}{l}\text { Incorrect } \\
\text { passive form }\end{array}$ & $\begin{array}{l}\text { the solution } \\
\text { is made in } \\
\text { Indonesia }\end{array}$ \\
\hline 4 & $\begin{array}{l}\text { Jogja also } \\
\text { become city }\end{array}$ & $\begin{array}{l}\text { Incorrect } \\
\text { subject-verb } \\
\text { agreement- } \\
\text { become }\end{array}$ & $\begin{array}{l}\text { Yogya also } \\
\text { becomes city }\end{array}$ \\
\hline 5 & $\begin{array}{l}\text { because } \\
\text { they has } \\
\text { travelling in } \\
\text { mountain }\end{array}$ & $\begin{array}{l}\text { Incorrect } \\
\text { Verb }\end{array}$ & $\begin{array}{l}\text { because they } \\
\text { have been } \\
\text { travelling in } \\
\text { mountain }\end{array}$ \\
\hline 6 & $\begin{array}{l}\text { Manage the } \\
\text { time to } \\
\text { study }\end{array}$ & $\begin{array}{l}\text { Minus } \\
\text { subject }\end{array}$ & $\begin{array}{l}\text { They manage } \\
\text { the time to } \\
\text { study }\end{array}$ \\
\hline 7 & $\begin{array}{l}\text { school } \\
\text { policy very } \\
\text { difficult }\end{array}$ & Minus verb & $\begin{array}{l}\text { school policy } \\
\text { is very } \\
\text { difficult }\end{array}$ \\
\hline 8 & $\begin{array}{l}\text { Every } \\
\text { school have } \\
\text { four or five } \\
\text { securities }\end{array}$ & $\begin{array}{l}\text { Incorrect } \\
\text { verb-have }\end{array}$ & $\begin{array}{l}\text { Every school } \\
\text { has four or } \\
\text { five securities }\end{array}$ \\
\hline 9 & $\begin{array}{l}\text { when he } \\
\text { work }\end{array}$ & $\begin{array}{l}\text { Incorrect } \\
\text { subject-verb } \\
\text { agreement - } \\
\text { work }\end{array}$ & $\begin{array}{l}\text { when he } \\
\text { works }\end{array}$ \\
\hline 10 & $\begin{array}{l}\text { When on } \\
\text { the street }\end{array}$ & $\begin{array}{l}\text { Minus } \\
\text { subject and } \\
\text { verb }\end{array}$ & $\begin{array}{l}\text { When she } \\
\text { was on the } \\
\text { street }\end{array}$ \\
\hline
\end{tabular}




\begin{tabular}{clll}
\hline 11 & $\begin{array}{l}\text { The } \\
\text { techniques } \\
\text { also to gain }\end{array}$ & $\begin{array}{l}\text { Minus verb- } \\
\text { are }\end{array}$ & $\begin{array}{l}\text { The } \\
\text { techniques } \\
\text { are also to } \\
\text { gain }\end{array}$ \\
\hline 12 & $\begin{array}{l}\text { When we } \\
\text { speak } \\
\text { sometime } \\
\text { make some }\end{array}$ & $\begin{array}{l}\text { Minus } \\
\text { punctuation } \\
\text { (,) and } \\
\text { subject at } \\
\text { independent } \\
\text { clause }\end{array}$ & $\begin{array}{l}\text { When we } \\
\text { speak, } \\
\text { sometime we } \\
\text { make some }\end{array}$ \\
& & $\begin{array}{l}\text { Minus verb- } \\
\text { are }\end{array}$ & $\begin{array}{l}\text { When } \\
\text { students are } \\
\text { not familiar }\end{array}$ \\
\hline & $\begin{array}{l}\text { When } \\
\text { students not } \\
\text { familiar }\end{array}$ & Table 5. Clause Syntactic Error in Essay Writing
\end{tabular}

There were thirteen clauses syntactic errors. They were divided into seven types of error. First was to be before modal as shown on table 5 number 1 like it $\underline{i s}$ can make many traffic problems. This error should be changed into it can make many traffic problems because this clause did not need to be before modal. Modals always appear before subject of a sentence, and always followed by v1. The number of this error was one. Second was incorrect subject-verb agreement as shown on table 5 number 2, 4, and 9. An example of this error was when he work which should be changed into when he works. The verb work in that clause needs a letter s. subject-verb agreement must follow the rules of English grammar. If there is a singular subject, a verb must also be singular. If there is a plural subject, a verb must also be plural. The number of this error was three. Third was incorrect passive form as shown on table 5 number 5 like the solution is be made in Indonesia. This clause should be changed into the solution is made in Indonesia because that clause used simple present tense, so the formula of passive form in that clause is subject + to be $+v 3$. Some university students get confused between to be and be. Some of them think that to be in passive form pattern is be. The number of this error was one. Fourth was incorrect verb of has/have as shown on table 5 number 5 and 8. An example of this error was Every school have four or five securities. This error should be changed into Every school has four or five securities because every refers to singular. In this error, some students also get difficult to identify the use of has and have in a clause. Some of them assume that they are similar. The number of this error was two. Fifth was minus subject as shown on table 5 number 6, 10, and 12. An example of this error was Manage the time to study. This error should be changed into They manage the time to study because a minimal requirement of a clause is subject and verb.
A clause cannot be called as a clause if it does not have both of them. If they only have a subject without a verb, it is not a clause, it may be called a phrase or only a string of words. The number of this error was three. Sixth was minus verb as shown on table 5 number 7, 10, 11, and 13. An example of this error was school policy very difficult. This error should be changed into school policy is very difficult because a clause must have at least subject and verb. A verb in that clause is in the form of to be that is is. The number of this error was four. Seventh was minus punctuation as shown on table 5 number 12 like When we speak sometime make some. This error should be changed into When we speak, sometime we make some because punctuation comma was needed if a sentence used subordinating conjunction at the beginning. The number of this error was one.

The most clause errors did by university students in English essay writing were minus verb, minus subject, and incorrect subject-verb agreement. Furthermore, those three main errors and other errors in clause syntactic errors were closely related to incomplete part of the clause which means there is a missing part. It may miss subject or verb. It can also be said that they happened because of some university students' weakness in English grammar which means they do not know it well. It also happened because they did not have preparation of writing, so they only wrote it. They did it like they were speaking. Talking everything without paying attention to the rules of English grammar.

The seven types of phrase syntactic errors can be seen on table 6 below:

\begin{tabular}{|c|c|c|}
\hline No & Word Syntactic Errors & Total \\
\hline 1 & to be before modal & 1 \\
\hline 2 & $\begin{array}{ll}\text { Incorrect } & \text { subject-verb } \\
\text { agreement } & \end{array}$ & 3 \\
\hline 3 & Incorrect passive form & 1 \\
\hline 4 & Incorrect verb of has/have & 2 \\
\hline 5 & Minus subject & 3 \\
\hline 6 & Minus verb & 4 \\
\hline 7 & Minus punctuation & 1 \\
\hline
\end{tabular}

\section{CONCLUSION}

According to this study, some university students made some words, phrases, and clauses syntactic errors. The word syntactic errors were divided into 
seven namely inverted position of a letter in a word, excess letter at the end of a word, excess letter at the middle of a word, minus letter at the end of a word, minus letter at the middle of a word, incorrect initial letter of city name, and incorrect letter in a word. The phrase syntactic errors were divided into eight namely incorrect pattern of parallel structure, to be before modal, to $+\mathrm{v} 2 / \mathrm{v} 3$, incorrect plural form of a word, incorrect singular form of a word, incorrect use of article $a$, minus be after modal, and incorrect pattern of English noun phrase. The clause syntactic errors were divided into seven namely to be before modal, incorrect subject-verb agreement, incorrect passive form, incorrect verb of has/have, minus subject, minus verb, and minus punctuation.

The main causes of syntactic errors are divided into two. First was word syntactic errors which were influenced by the pronunciation of English. Some university students often wrote words according to how they are pronounced. They missed the right written form of a word. It seems difficult for them to memorize the written form because they wrote what was on their mind. Second was phrases and clauses syntactic errors occurred due to lack of understanding of English grammar. Those errors were also influenced by Indonesian grammar which means that some university students are not able to use English grammar properly because of their Indonesian language. It becomes serious problem because Indonesian and English language have different pattern.

All syntactic errors in English essay writing can be minimize by doing three steps. First is practicing to write English essay twice a week. It means they must write any English essay in a week. It can be short or long English essay as long as they love it. Practicing twice a week will help them to improve their syntactic part in English essay writing. Second is rechecking their written English essay. By doing it, they will know which parts are incorrect. Then learning from their own mistakes is the best way to avoid similar mistakes in English essay writing. Third is correcting their mistakes. After rechecking their English essay, it would be better if they correct their mistakes. It will help them to memorize the pattern in English grammar, so they will not do the same mistakes in the future. Moreover, there is one important part to minimize syntactic errors in English essay writing that is mastering English grammar. It must be done by university students because English grammar always relates to syntactic part, and university students who master it well will be able to write a good essay. It means they are able to deliver the messages on their English essay writing to their readers because they can read them well.

\section{ACKNOWLEDGEMENT}

This study was fully supported by English Education Program especially Ms. Dita Surwanti S.S., M.Hum and LP3M Universitas Sarjanawiyata Tamansiswa Yogyakarta.

\section{REFERENCES}

[1] Savage, Alice \& Mayer, Patricia. 2006. Effective Academic Writing 2. New York: Oxford University Press.

[2] Tallerman, Maggie. 2015. Understanding Syntax. Oxon: Routledge.

[3] Ramlan, Muhammad. 1983. Sintaksis. Yogyakarta: Karyono.

[4] Richard, K Larson. 1985. Natural Language and Linguistics Theory. US: Springer.

[5] Chaer, Abdul. 2003. Linguistik Umum. Jakarta: PT Rineka Cipta.

[6] Mahsun. 2013. Metode Penelitian Bahasa: Tahapan strategi, metode, dan tekniknya. Jakarta: PT RajaGrafindo Persada.

[7] Promsupa, P.,Varasarin, P., \& Brudhiprabha, P. "An analysis of grammatical errors in English writing of Thai university students", Human Resource Development Journal, 8(1), 2017, 267296.

[8] Sawalmeh, Murad Hasan M. 2013. Error Analysis of Written English Essays: The Case of Students of the Preparatory Year Program in Saudi Arabia. English for Specific Purposes World. Issue 40 Vol. 14 pp. 1-17.

[9] Saldana, Johnny. 2011. Fundamentals of Qualitative Research. New York: Oxford University Press. 